\title{
Antimutagenic Activities Extracts from Leaves of the Morus alba, Morus nigra and Their Mixtures
}

\author{
R. A. Agabeyli \\ Institute of Botany, Azerbaijan National Academy of Sciences \\ 40, Batamdar Shosse, Baku AZ1073, Azerbaijan \\ E-mail: renaagabey1@rambler.ru
}

Received: February 9, 2012

Accepted: February 25, 2012

Published: April 1, 2012

doi:10.5539/ijb.v4n2p166

URL: http://dx.doi.org/10.5539/ijb.v4n2p166

\begin{abstract}
The influence of Morus alba and Morus nigra leaf extracts, and their mixture on the structure and functions of plants and animals cells were studied. The absence of the genotoxicity of the extracts and their mixture has been established. All active biological compounds studied demonstrate genoprotective properties. The studied extracts and their mixtures decreased the mutability level induced with chemical mutagens, gamma-rays and ageing in the plants (Vicia faba, Arabidopsis thaliana) and animals (rats) cells.
\end{abstract}

Keywords: Antimutagens, Genoprotectors, Plant extracts, Gamma-Rays, Ageing, Morus alba, Morus nigra

\section{Introduction}

Biologically active compounds obtained from the different plant species have a potential to positively influence health and longevity and can be used as food additives (Surh et al., 1995; Cardaror-Martinez et el., 2002; Romina et al., 2006, Agabeyli, 2008; Weisburger, 2002). A use of biologically active compounds as nutritional supplements/food additives allows enhancing quality of food and provides food products with new features. This approach increases competitiveness among food industry products and results in higher sales and expansion of markets.

Nutritional supplements are different in nature and belong to different classes of natural and synthetic-chemical compounds and their complexes. The most promising food additives and supplements usually originate from plants. While additives of herbal origins are normally most suitable for the use in food industry, a thorough assessment is necessary in order to rule out substances with possible side effects and confirm health benefits. The results of numerous past studies, aimed at assessment of genetic activity of composite antimutagens or food additives with genoprotective properties, demonstrate that these qualities are manifested best by the mixtures of several agents, rather than by the individual components (Alakbarov, 2002; Agabeyli et al., 2005; Alakbarov et al., 2002).

The aim of this study was to conduct a comprehensive assessment of the influence of herbal extracts obtained from the leaves of species on the levels of chromosome mutations induced by chemical products and radiation. Morus alba and Morus nigra species are widely distributed throughout the territory of Azerbaijan Republic, and may be considered as a source of promising and effective nutritional supplement/food additive for various food industries.

\section{Materials and Methods}

2.1 Research objects

2.1.1 Plants

1) Beans - (Vicia faba L.), 2) Arabidopsis (Arabidopsis thaliana)

2.1.2 Animals

Wistar rats, aged 10-12 weeks (weighing 120-130 g). 


\subsection{Inductors of mutation process}

1). Gamma-rays (GR), the seeds of $V$. faba were exposed to installing $\mathrm{K}-25, \mathrm{Co}^{60}$, in a dose $60 \mathrm{~Gy}$; animals in a dose of $3 \mathrm{~Gy} .2$ ). Chemical mutagens: N-methyl ${ }^{1}$-nitro-N-nitrozoguanidin (MNNG), the firm "Serva"-direct-type action on DNA, in concentrations $-1 \mathrm{mM} ; 3 \mathrm{mM}$, 3). Sodium fluoride - NaF, in concentrations $-20 \mathrm{mg}$ fluorine per $100 \mathrm{~g}$ weight of the animal.

\subsection{Modifiers of mutation process}

Water-ethanol extracts from leaves of M. alba - variety Bidan (E1) and black mulberry M. nigra - variety Har here (E2), and their mixture - composition (CP) with a high content of amino acids, antioxidants, and vitamin C.

\subsection{Methods}

Analysis of gene mutations was performed on a Mueller's embryonic test (Arabidopsis thaliana) (Müller, 1963). Analyses of chromosome aberrations in the anaphase in plants cells and statistics data processing have been done according standard procedures [Agabeyli et al., 2011].

Plant extracts (E1, E2 and CP) were obtained by vacuum distillation, consisting of the stages of extraction, purification of ballast substances and evaporation (Muraviev, 1978) at the Department of Pharmacognosy and Botany of the Azerbaijan State Medical University.

\section{Results and Discussion}

Results of comparative evaluation of the influence of extracts - E1, E2, and their mixture (CP) on spontaneous mutations levels and mutations induced by aging and environmental xenobiotics in the cells of plant and animal test systems are summarized below.

The Morus leaves are rich in amino acids, vitamin C and antioxidants (Luo, 1994), which have known with antimutagenic activities (Agabeyli, 2008). The results of the evaluation of the genetic activity of E1, E2 and CP in experiments on $V$. faba seeds having a high level of spontaneous mutations of chromosomes revealed a high level of antimutagenic activity (AA) in all ranges of studied concentrations (Table 1). With increasing concentration of the studied extracts within the range of $1-100 \mathrm{mkg} / \mathrm{ml}$ their effectiveness in preventing frequency of chromosomes aberrations exceeded $50 \%$ of control level. The same effect was observed during the assessment of E2 effectiveness. However, the antimutagenic effect of $\mathrm{CP}$ on aging-induced frequency of chromosome aberration was even more prominent as compared to control. In high concentrations of E1, E2, CP did not demonstrate any mutagenic or other toxic activity.

Results of experiments demonstrate higher antimutagenic and gene-protective activities of $\mathrm{CP}$ as demonstrated by the modification of ageing induced chromosome aberrations levels in the cells of $V$. faba where mixture of extracts (CP) demonstrated reduction of the level of the aberrations of chromosomes by $84-86 \%$, exceeding the antimutagenic efficiency of the components used separately (Table 2). Both studied extracts demonstrated gene protection activity in modification of chromosome aberrations level induced by chemical mutagen MNNG in cells of $V$. faba. Antimutagen efficiency of CP was confirmed for studied concentrations and ranged from $70 \%$ to $86 \%$ as compares to control levels. Similar to E1 and E2, efficiency of CP increased in higher concentrations $(1-100 \mathrm{mkg} / \mathrm{ml})$ and reached $84-86 \%$.

To examine universality of the effects of plants extracts and their mixture, different test systems were used. Test-object $A$. thaliana has a short life cycle (30 days), it is easy to cultivate in the laboratory and allows analyzing the influence of various factors on the frequency of gene mutations (Ivanov, 1974). The results of comparative evaluation of antimutagenic activity of E1, E2 and CP on the frequency of dominant embryonic chlorophyll mutations induced by MNNG in A. thaliana, revealed higher efficiency of mixture of extracts (CP) as compares to the separate use of the composites (Table 3).

Antimutagen's assessment standards require comprehensive examination of universality and specificity of their effectiveness in reducing chromosome instability induced by genotoxicants with different mechanism of action.

Therefore ionizing irradiation (gamma-rays) and environmental chemical mutagen $(\mathrm{NaF})$ were used as mutagenic factors in the experiments. Ionizing radiation is a potential DNA damaging agent. Comparative analysis of successful reduction of radiation-induced chromosome aberrations rate by the plant extracts E1 and E2 and their mixture CP is presented in the Table 4. Under the influence of GR frequency of chromosome aberrations in bone marrow cells of rats increases relatively to control more than 9 times (Table 4).

Prior to exposure (12 days), prophylactic injection of herbal extracts decreases cellular chromosomes aberrations rate induced by GR and efficiency of antimutagenic effects exceeded $50 \%$ level in all variations of the 
experiment. With increasing concentration of extracts E1, E2 and CP their antimutagenic efficiency respectively varied from 58 to $68 \%, 64-70 \%$ and $77-83 \%$.

Fluorine mutagens are known environmental genotoxicants (Aaderma et al., 1989; Tsebyujinskiy et al., 1981). Sodium fluoride $\mathrm{NaF}$ is widely used in various branches of ferrous metallurgy, medicine and everyday life. NaF is known to impact DNA repair mechanisms (10, Aaderma et al., 1989; Tsebyujinskiy et al., 1981). Therefore, in a series of experiments antimutagen efficiency of plant extracts and their mixtures was studied on $\mathrm{NaF}$ induced mutations process in rat's bone marrow cells. A preliminary two-week introduction of plant extracts to the standard diet of rats did not lead to the manifestation of mutagenic and other side effects (Table 5). In animals with $\mathrm{NaF}$ - induced high levels of chromosome mutations use of E1, E2 and CP effectively reduced levels of chromosome aberrations, E1 and E2 reduced these levels by to $53-59 \%$ and CP by more than $66-78 \%$ as compares to control.

Comparative assessment of antimutagen efficiency in variations of experiment shows higher efficiency of extracts mixture (CP) in prevention of NaF - induced mutations of chromosomes (Table 5).

The majority of the known plant antimutagens demonstrated the effectiveness in decreasing the level of generational and regulation disorders induced by different environmental xenobitics, including the mutagens and carcinogens with different mechanisms of action. The experiments shown that studied extracts demonstrated effectiveness against the mutability induced also by ageing processes. The antimutagenic effectiveness is associated with the multicomponent nature of the studied extracts and their mixtures. Therefore the creation of the plants extracts compositions and their mixtures with is a real way for increasing of their effectiveness in prevention of the genetically disorders induced by environmental xenobiotics (Alakbarov, 2002).

The results of the research also indicate that introduction of the extracts into the standard diet of the animals two weeks prior to the experiments did not lead to manifestation of mutagenic or any other side effects (Table 5). Extracts from the fruits of Black Morus nigra L., White mulberry Morus alba L. and Red mulberry Morus rubra L. mulberry have high content of ascorbic acid, amino acids, glucose, minerals, tannins and triterpenes and demonstrate antioxidant properties (Ercizli et al., 2007, 2008, Ozgen et al, 2009; Soni et al.,1999). Experiments with three flavonoids from Morus alba L. - Morusine (morusin), kuvanon H (Kuvanon H) and morusin 4'-glucoside (morusin 4 '- glycoside) and their derivatives revealed their sensitivity to photooxidation and the manifestation of anti - HIV activity in vitro. The authors are the first to report anti - HIV activity and cytotoxicity of morusin - 2 '-glucoside, morusin - 4'-glucoside, kuvanon H-6' - aoctare kuvanon H-7-acetate and triacetate malberroforan D (Luo, 1994). There is now ample evidence of the antimutagenic effect of phenolic compounds (Agabeyli, 2008, Ercisli et al, 2007, 2008), including the protective effect of dietary supplementation with phenolic compounds against aflatoxin-induced mutagenicity and hepatocarcinogenicity (Soni et al., 1999); antimutagenic effect of natural phenolic compounds of beans (De Mejia et al., 1999) and others [Smerak et al., 2002; Masuda et al., 1999; Rice-Evans et al., 1997; Eman et al., 2008; Kutlu et al. 2011; Owen et al., 2000; Kaur et al, 2002; Cai et al., 2004).

Research in biologically active compounds obtained from the different plant species shows that they do not exhibit genotoxic and cytotoxic properties and are of interest for further studies for the prospective use as dietary supplements/food additives that have antioxidant and antimutagenic activity. This study suggests that these compounds exhibit considerable gene protective properties, which have a potential to greatly enhance their future use in the food industry (Surh et al., 1995; Weisburger, 2002; Agabeyli et al., 2005: Alakbarov et al., 2002). The practical application of plant composition to neutralize the mutagenic effect of environmental genotoxicants may be one of the practical ways to improve the nutritional value and competitiveness of food products. Studied extracts demonstrate strong gene protection properties, which significantly increase value of their possible use in food industry. Use of herbal extracts in food industry to provide valuable source of antimutagenic protection is a promising way to increase nutritional value and competitiveness of food industry products.

\section{References}

Aaderma M. I., Gibson D. P., \& Le Boeuf R. A. (1989). Sodium fluoride-induced chromosome aberrations in different stages of the cell cycle: a proposed mechanism. Mutat. Res. Genet. Toxicol Test, 223(2), 191-203. http://dx.doi.org/10.1016/0165-1218(89)90047-5

Agabeili R. A., \& Mirzazade G. G. Study of the Genoprotective Properties of Oils from Fruits and Leaves of Fagus orientalis Lipsky. J. Cytology and Genetics, 45(4), 220-224.

Agabeyli R. A. (2008). Bioantioksidanty: rol' v geneticheskoi ustoichivosti i okhrane bioraznoobraziya (Bioantioxidants: Their Role in Genetic Stability and Biodiversity). Baku: Elm. 
Agabeyli R. A., \& T. E. Gasimova. (2005). Antimutagenic activity of Armoracia rusticana, Zea mays and Ficus carica plant extracts and their mixture. J. Cytologu and Genetics, 3, 75-79.

Agabeyli R. A., F. R. Zeinalova, \& G. G. Mirza-zadeh. (1998). Antimutagenic properties of Morus alba exstract under induction of mutations in Arabidopsis thaliana by chemical mutagens. Arcachon, 25-29.

Alakbarov U. K. (2002). Plant antimutagens and their mixtures in inhibition of genotoxic effects of xenobiotics and aging processes. European J. of Cancer Prevention, 11 (suppl 2). S8-S11.

Alekperov U. K., Mirzazadeh G. G., \& Agabeyli R. A. (2002). Inhibition by compositional plant antimutagens the xenobiotics iduced mutability in Vicia faba. J. Drug Metabolism Reviews, 34(suppl. 1), 93-186.

Cai Y., Luo O., Sun M., et al. (2004). Antioxidant activity and phenolic compounds of 112 traditional Chinese medicinal plant associated with anticancer. Life Sci, 74, 2157-2184. http://dx.doi.org/10.1016/j.lfs.2003.09.047

Cardaror-Martinez, A., Castano-Tostado, E., \& Loarco-Pina, G. (2002). Antimutagenic activity of natural phenolic compounds present in the common bean (Phaseolus vulgaris) against aflatoxin $\mathrm{B}_{1}$. Food Addit. Contam, 19, 62-69. http://dx.doi.org/10.1080/02652030110062110

De Mejia E. G., Castano-Tostado E., Loarca -Pina G. (1999). Antimutagenic effect of natural phenolic compounds in beans. J. Mutat. Res, 441, 1-9.

Eman M. G., Adel M, Elbehairy, \& Magdu A. G. (2008). Antimutagenic Efficiency of Some Natural Compounds on Cyclophosphamide - Indused p53 Alterations. Naturforsch, 63, 857-863.

Ercisli S., \& Orhan E. (2007). Chemical composition of white (Morus alba) red (Morus rubra) and black (Morus nigra) mulberry fruits. Food Chemistry, 103(4), 1380-1384. http://dx.doi.org/10.1016/j.foodchem.2006.10.054

Ercisli S., \& Orhan E. (2008). Some physico-chemical characteristics of black mulberry (Morus nigra L.) genotypes from Northeast Anatoloia region of Turkey. Scientia Horticulturae, 116 (1), 41-46. http://dx.doi.org/10.1016/j.scienta.2007.10.021

Ivanov I. I. (1974). Radiobiologiya i genetika arabidopsisa (Radiobiology and genetics of arabidopsis). Arabidopsis thaliana, 125-134.

Kaur C., \& (2002). Kapoor H. C. Antioxidant activity and total phenolic content of some Asian vegetables. Int. J. Food Sci. Technol., 37, 153-161. http://dx.doi.org/10.1046/j.1365-2621.2002.00552.x

Kutlu T., Durmaz G., Ateş B., Yilmaz I., \& Ģetin Ş. (2011). Antioxidant properties of different extracts of black mulberry. Turkish Journal of Bilogy, 35(1), 103-111.

Luo S. D., Nemec J., Ning B. M., \& Li Q. X. (1994). Anti-HIV flavonoids from Morus alba L. San Baipi root of Morus alba L. (Moraceae) is traditional Chinese medicine. Int. Conf. AIDS, 10, 203.

Masuda T., Yenomori S., Oyama Y., et al. (1999). Evolution of the antioxidant activity of environmental plants: activity of the leaf extracts from seashore plants. J. Agr. Food Chem, 47, 1749-1754. http://dx.doi.org/10.1021/jf980864s

Müller A. J. (1963). Enbryonen test zum Nachweis rezessiver letalfaktoren bei Arabidopsis thaliana. Biol. Zbl., 82, 133.

Muraviev I. A. (1978). Technology of medical drugs. M. "Medicine”, p. 143-224.

Owen R. W., Mier, W., Giacosa, A., Hull, W. E. Spiegelhalder, B., \& Bartsch, H. (2000). Phenolic compounds and squalene in olive oils: the concentration and antioxidant potential of total phenols, sinple phenols, secoiridoids, lignanas and squalene. Food Chem. Toxicol, 38, 647-659. http://dx.doi.org/10.1016/S0278-6915(00)00061-2

Özgen M., Serçe, S., \& Kaya C. (2009). Phytochemical and antioxidant properties of anthocyanin-rich Morus nigra and Morus rubra fruits. Scientia Horticulturae, 119(3), 275-279. http://dx.doi.org/10.1016/j.scienta.2008.08.007

Rice-Evans, C. A., Millere, N. J., Paganga, G. (1997). Antioxidant properties of phenolic compounds. Trends Plant Sci., 2, 152-159. http://dx.doi.org/10.1016/S1360-1385(97)01018-2

Romina P., Cisneros-Zevallos L. (2006). Antimutagenic and Antioxidant Properties of Phenolic Fractions from Andean purple Corn (Zea mays L.). J. Agric. Food Chem., 54, 4557-4567. http://dx.doi.org/10.1021/jf0531050 
Šmerak P., Šestaková H., Polivková Z., et al. (2002). Antimutagenic Effects oif Ellagic Acid and its Effect on the Immune Response in Mice. Chech J. Food Sci., 20(5), 181-191.

Soni K. B., Lahiri M., Chackradeo P., Bhide S. V., Kutton R. (1999). Protective effect of food additives on aflotoxin-induced mutagenicity and hepatocarcinogenicity. Cancer Lett, 115, 129-133. http://dx.doi.org/10.1016/S0304-3835(97)04710-1

Surh Y. J., Park K. K., \& Miller J. A. (1995). Anticarcinogenic and antimutagenic activity of chlorophillin, a potential chemopreventive agent. The Intern.Toxigologist. Seattle, Washington. USA. Abstr. of the Intern. Congress of Toxigology, 84, 5.

Tsebyujinskiy O. I., Potyajenko M. M., \& Malich V. I. (1981). Eksperimentalnie I kliniceskie issledovaniya pri intoksikatsii ftorom (Experimental and clinical research of intoxication by fluorine). $\mathrm{V}$ kn.: Biofizicheskie i fiziko-ximicheskie issledovaniya v vitaminologii. M.: Nauka, 74- 76.

Weisburger J. H. (2002). Lifestyle, health and disease prevention: the underlying mechanisms. European J. of Cancer Prevention, 11(Suppl 2), S1-S7.

Table 1. Effect of extracts from of leaves Morus alba (E1), Morus nigra (E2) and their composition (CP) on the frequency of chromosome aberrations in meristematic cells of roots of the $V$. faba

\begin{tabular}{|c|c|c|c|c|c|c|}
\hline \multirow{2}{*}{$\begin{array}{c}\text { Experiment } \\
\text { variations }\end{array}$} & \multirow{2}{*}{$\begin{array}{c}\text { Concentration, } \\
\mathrm{mkg} / \mathrm{ml}, \mathrm{NG}, \\
\mathrm{MM}\end{array}$} & \multirow{2}{*}{$\begin{array}{l}\text { Number } \\
\text { of cells } \\
\text { studied }\end{array}$} & \multicolumn{2}{|c|}{ Cells with CA, \% } & \multirow[t]{2}{*}{$\mathrm{Td}$} & \multirow[t]{2}{*}{$\mathrm{AE}^{*}, \%$} \\
\hline & & & $\mathrm{N}$ & $\mathrm{M} \pm \mathrm{m}$ & & \\
\hline $\mathrm{O}$ (control) & - & 899 & 63 & $7.19 \pm 0.86$ & - & - \\
\hline \multirow[t]{6}{*}{ E1 } & 100 & 840 & 24 & $2.85 \pm 0.32$ & 4.6 & 60 \\
\hline & 10 & 820 & 19 & $2.31 \pm 0.27$ & 4.5 & 67 \\
\hline & 1 & 930 & 22 & $2.36 \pm 0.24$ & 3.5 & 67 \\
\hline & 0.1 & 994 & 26 & $2.61 \pm 0.25$ & 4.0 & 63 \\
\hline & 0.01 & 954 & 25 & $2.62 \pm 0.26$ & 2.5 & 63 \\
\hline & 0.001 & 1125 & 49 & $4.35 \pm 0.36$ & 2.8 & 39 \\
\hline \multirow[t]{6}{*}{ E2 } & 100 & 1009 & 29 & $2.87 \pm 0.52$ & 4.9 & 60 \\
\hline & 10 & 1100 & 31 & $2.81 \pm 0.49$ & 4.4 & 60 \\
\hline & 1 & 1007 & 30 & $2.97 \pm 0.53$ & 4.1 & 58 \\
\hline & 0.1 & 949 & 32 & $3.37 \pm 0.58$ & 3.7 & 53 \\
\hline & 0.01 & 1020 & 37 & $3.62 \pm 0.55$ & 3.4 & 49 \\
\hline & 0.001 & 1038 & 39 & $3.75 \pm 0.58$ & 3.3 & 47 \\
\hline \multirow[t]{6}{*}{$\mathrm{CP}$} & 100 & 940 & 16 & $1.70 \pm 0.17$ & 4.8 & 76 \\
\hline & 10 & 1058 & 13 & $1.22 \pm 0.11$ & 6.3 & 83 \\
\hline & 1 & 936 & 14 & $1.49 \pm 0.15$ & 5.9 & 79 \\
\hline & 0.1 & 996 & 18 & $1.80 \pm 0.31$ & 6.1 & 74 \\
\hline & 0.01 & 620 & 20 & $3.22 \pm 0.70$ & 3.5 & 55 \\
\hline & 0.001 & 750 & 25 & $3.33 \pm 0.42$ & 6.1 & 53 \\
\hline
\end{tabular}

$\mathrm{AE}^{*}$ - antimutagenic efficiency. 
Table 2. Effects of extracts from Morus alba (E1), Morus nigra (E2) and their compositions (CP) on and MNNG-induced (1 $1 \mathrm{MM})$ frequency of chromosome aberrations in the root meristem cells of Vicia faba

\begin{tabular}{|c|c|c|c|c|c|c|}
\hline \multirow{2}{*}{$\begin{array}{c}\text { Experiment } \\
\text { variations }\end{array}$} & \multirow{2}{*}{$\begin{array}{c}\text { Concentration, } \\
\mathrm{mkg} / \mathrm{ml}, \mathrm{NG}, \\
\mathrm{MM}\end{array}$} & \multirow{2}{*}{$\begin{array}{l}\text { Number } \\
\text { of cells } \\
\text { Studied }\end{array}$} & \multicolumn{2}{|c|}{ Cells with CA, \% } & \multirow[t]{2}{*}{$t_{d}$} & \multirow[t]{2}{*}{$\mathrm{AE}, \%$} \\
\hline & & & $\mathrm{N}$ & $\mathrm{M} \pm \mathrm{m}$ & & \\
\hline $\mathrm{O}$ (control) & - & 899 & 63 & $7.19 \pm 0.86$ & - & \\
\hline MNNG & 1 & 959 & 145 & $15.98 \pm 1.21$ & - & \\
\hline \multirow{6}{*}{ E1 } & 100 & 703 & 50 & $7.82 \pm 1.05$ & 4.6 & 70 \\
\hline & 10 & 1008 & 82 & $8.13 \pm 0.86$ & 5.2 & 64 \\
\hline & 1 & 1010 & 89 & $9.71 \pm 1.11$ & 4.7 & 57 \\
\hline & 0.1 & 893 & 79 & $8.84 \pm 0.94$ & 5.0 & 61 \\
\hline & 0.01 & 906 & 72 & $7.94 \pm 0.89$ & 5.3 & 70 \\
\hline & 0.001 & 1099 & 79 & $7.18 \pm 0.81$ & 8.8 & 74 \\
\hline \multirow{6}{*}{ E2 } & 100 & 954 & 40 & $4.19 \pm 0.42$ & 9.2 & 73 \\
\hline & 10 & 749 & 30 & $4.00 \pm 0.71$ & 8.5 & 74 \\
\hline & 1 & 895 & 42 & $4.69 \pm 0.49$ & 8.6 & 70 \\
\hline & 0.1 & 948 & 51 & $5.37 \pm 0.73$ & 7.5 & 66 \\
\hline & 0.01 & 999 & 60 & $6.0 \pm 0.28$ & 8.0 & 77 \\
\hline & 0.001 & 1000 & 60 & $6.0 \pm 0.28$ & 8.0 & 77 \\
\hline \multirow{6}{*}{$\mathrm{CP}$} & 100 & 516 & 13 & $2.51 \pm 0.71$ & 9.4 & 84 \\
\hline & 10 & 1614 & 34 & $2.10 \pm 0.40$ & 10.3 & 86 \\
\hline & 1 & 735 & 18 & $2.44 \pm 0.35$ & 10.7 & 84 \\
\hline & 0.1 & 849 & 22 & $2.59 \pm 0.54$ & 10.1 & 80 \\
\hline & 0.01 & 985 & 30 & $3.04 \pm 0.54$ & 9.7 & 80 \\
\hline & 0.001 & 857 & 27 & $3.15 \pm 0.58$ & 3.0 & 80 \\
\hline
\end{tabular}

$\mathrm{AE}^{*}$ - antimutagen efficiency.

Table 3. Analysis of frequency of dominant embryonic chlorophyll mutations induced by (MNNG, $3 \mathrm{mM})$ in Arabidopsis thaliana and their modification of extracts from Morus alba (E1) and Morus nigra (E2) and their composition (CP)

\begin{tabular}{|c|c|c|c|c|c|}
\hline \multirow{2}{*}{$\begin{array}{l}\text { Experiment } \\
\text { variations }\end{array}$} & \multirow{2}{*}{$\begin{array}{l}\text { Number } \\
\text { of cells } \\
\text { studied }\end{array}$} & \multicolumn{2}{|c|}{ Cells with CA, \% } & \multirow[t]{2}{*}{ td } & \multirow[t]{2}{*}{$\mathrm{AE}, \%$} \\
\hline & & $\mathrm{N}$ & $\mathrm{M} \pm \mathrm{m}$ & & \\
\hline 0 (control) & - & - & 0.02 & - & - \\
\hline MNNG & 240 & 62 & $25.83 \pm 2.82$ & 5.6 & - \\
\hline $\mathrm{MNNG}+\mathrm{E} 1,30 \mathrm{mkg} / \mathrm{ml}$ & 390 & 35 & $8.97 \pm 1.44$ & 5.3 & 62 \\
\hline $\mathrm{MNNG}+\mathrm{E} 160 \mathrm{mkg} / \mathrm{ml}$ & 435 & 27 & $6.20 \pm 1.15$ & 5.6 & 75 \\
\hline $\mathrm{MNNG}+\mathrm{E} 2,30 \mathrm{mkg} / \mathrm{ml}$ & 460 & 30 & $6.52 \pm 1.15$ & 6.7 & 74 \\
\hline $\mathrm{MNNG}+\mathrm{E} 2,60 \mathrm{mkg} / \mathrm{ml}$ & 460 & 28 & $6.08 \pm 1.11$ & 6.6 & 74 \\
\hline $\mathrm{MNNG}+\mathrm{CP}, 30 \mathrm{mkg} / \mathrm{ml}$ & 374 & 25 & $6.68 \pm 1.29$ & 6.2 & 74 \\
\hline $\mathrm{MNNG}+\mathrm{CP}, 60 \mathrm{mkg} / \mathrm{ml}$ & 420 & 24 & $5.71 \pm 1.13$ & 6.6 & 77 \\
\hline
\end{tabular}

$\mathrm{P}<0.001$. 
Table 4. Effect of extracts from Morus alba (E1) and Morus nigra (E2) and their composition (CP) on the gamma-rays (GR) induced mutation process in bone marrow cells of rats

\begin{tabular}{|c|c|c|c|c|c|c|}
\hline \multirow{2}{*}{$\begin{array}{c}\text { Experiment } \\
\text { Variants }\end{array}$} & \multirow{2}{*}{$\begin{array}{l}\text { Concentration, } \\
\mathrm{mkg} / \mathrm{ml} ; \\
\text { mkg/100gr of } \\
\text { weight }\end{array}$} & \multirow{2}{*}{$\begin{array}{l}\text { Number } \\
\text { of cells } \\
\text { Studied }\end{array}$} & \multicolumn{2}{|c|}{ Cells with CA, $\%$} & \multirow[t]{2}{*}{ td } & \multirow[t]{2}{*}{$\mathrm{AE}, \%$} \\
\hline & & & $\mathrm{N}$ & $\mathrm{M} \pm \mathrm{m}$ & & \\
\hline $\mathrm{O}$ (control) & - & 1034 & 13 & $1.29 \pm 0.32$ & - & - \\
\hline GR & 3 & 1119 & 110 & $9.83 \pm 0.89$ & - & - \\
\hline \multirow[t]{2}{*}{$\mathrm{E} 1+\mathrm{GR}$} & 30 & 1005 & 44 & $4.37 \pm 0.64$ & 5.3 & 58 \\
\hline & 60 & 1130 & 37 & $3.27 \pm 0.52$ & 6.5 & 66 \\
\hline \multirow[t]{2}{*}{$\mathrm{E} 2+\mathrm{GR}$} & 30 & 1050 & 37 & $3.52 \pm 0.32$ & 5.9 & 64 \\
\hline & 60 & 1100 & 32 & $2.90 \pm 0.50$ & 6.7 & 70 \\
\hline \multirow[t]{2}{*}{$\mathrm{CP}+\mathrm{GR}$} & 30 & 1825 & 41 & $2.24 \pm 0.34$ & 7.9 & 77 \\
\hline & 60 & 1810 & 29 & $1.60 \pm 0.08$ & 8.8 & 83 \\
\hline
\end{tabular}

Table 5. Effect of extracts from Morus alba (E1) and Morus nigra (E2) and its composition (CP) on the frequency of spontaneous and $\mathrm{NaF}$ induced mutation process in bone marrow cells of rats

\begin{tabular}{|c|c|c|c|c|c|c|}
\hline \multirow[t]{2}{*}{$\begin{array}{c}\text { Experiment } \\
\text { Variants }\end{array}$} & \multirow{2}{*}{$\begin{array}{l}\text { Concentration, } \\
\mathrm{mkg} / \mathrm{ml}, \\
\mathrm{mg} / 100 \mathrm{~g} \text { of } \\
\text { weight }\end{array}$} & \multirow{2}{*}{$\begin{array}{l}\text { Number } \\
\text { of cells } \\
\text { Studied }\end{array}$} & \multicolumn{2}{|c|}{$\begin{array}{c}\text { Cells with } \mathrm{CA}, \% \\
\text { rate, }\end{array}$} & \multirow[t]{2}{*}{$\mathrm{t}_{\mathrm{d}}$} & \multirow[t]{2}{*}{$\mathrm{AE}, \%$} \\
\hline & & & $\mathrm{N}$ & Percent & & \\
\hline $\mathrm{O}$ (control) & - & 1835 & 29 & $1.58 \pm 0.28$ & - & - \\
\hline \multirow[t]{2}{*}{ E1 } & 30 & 1235 & 15 & $1.21 \pm 0.31$ & - & - \\
\hline & 60 & 1040 & 11 & $1.05 \pm 0.31$ & - & - \\
\hline \multirow[t]{2}{*}{ E2 } & 30 & 1325 & 11 & $1.05 \pm 0.28$ & - & - \\
\hline & 60 & 1200 & 10 & $0.83 \pm 0.28$ & - & 47 \\
\hline $\mathrm{CP}$ & - & 1089 & 7 & $0.64 \pm 0.24$ & 2.5 & 59 \\
\hline $\mathrm{NaF}$ & 20 & 2009 & 140 & $6.96 \pm 0.56$ & - & - \\
\hline \multirow[t]{2}{*}{$\mathrm{E} 1+\mathrm{NaF}$} & 30 & 1850 & 60 & $3.24 \pm 0.41$ & 5.3 & 53 \\
\hline & 60 & 1860 & 60 & $3.22 \pm 0.40$ & 5.4 & 53 \\
\hline \multirow[t]{2}{*}{$\mathrm{E} 2+\mathrm{NaF}$} & 30 & 1147 & 38 & $3.31 \pm 0.27$ & 5.8 & 52 \\
\hline & 60 & 1234 & 35 & $2.83 \pm 0.47$ & 5.6 & 59 \\
\hline \multirow[t]{2}{*}{$\mathrm{CP}+\mathrm{NaF}$} & 30 & 1780 & 41 & $2.30 \pm 0.35$ & 7.0 & 66 \\
\hline & 60 & 2010 & 30 & $1.49 \pm 0.27$ & 8.7 & 78 \\
\hline
\end{tabular}

